\title{
sciendo
}

\section{THEATRICAL MISE-EN-SCENE IN FILM FORM}

JÁN SABOL

Faculty of Arts, Pavol Jozef Šafárik University, Košice

\begin{abstract}
The study reflects on divergence between theatre and film. It also points out that the difference ought to be sought in ontology, in the principle of the coding of actual reality by using film or theatrical language. In the perception of a syncretic work that connects the elements of both types of art, the viewer a priori perceives theatrical mimesis (and also the execution of theatrical mise-en-scène) as an "alien" element used by the film "language" of a concrete cinematographic work. The perception of such a work assumes the viewer's readiness and willingness to accept a hybrid work, which inevitably calls for a different manner of decoding the narrative offered. If we are to summarise the hitherto knowledge which elucidates the relationship between theatre and film (in the manner in which actual reality is mimicked and in the subsequent execution of theatrical and film mise-en-scène), it may be concluded that, as opposed to film, theatre enjoys a unique opportunity to imitate actual reality by performing which takes place in real time and in direct interaction between the actor and the viewer. The film conveys this using filmmaking devices.
\end{abstract}

Key words: film, theatre, adaptation, lyrical, epic, dramatic

When contemplating a cinematographic work, we shall, sooner or later, be confronted with the issue of the interaction between theatre and film and between literature and film. The interference of various methods is symptomatic for these types of art and it has been taking place ever since the early days of filmmaking until the present, whereby it offers ever-new momenta to these types of art. Alongside the interaction between primarily theatrical and film methods the study will also cover the lyrical, epic and dramatic aspects of film. Even though the area in question is within the domain of genology and literary theory, the material with which genology works and also the questions posed transcend the limits of literary theory and overlap into other types of art. The phenomenon of the study and application of the theory of literary forms acquires a more universal use than just strictly literary and theoretical. In the presented study we base ourselves on the literary and theoretical points of departure of genology which are applied in a broader art research context, i.e. not only on literary text but also on film and theatre material.

"To me, more than anything else, film is theatre. It is not exactly the same theatre as that on stage. In a certain way, I prefer the one on stage. There, you are much less dependent on the 'unpredictability of mechanism'. No one will disprove the fact that film, all in all, is a kind of theatre, with more flexible and stricter rules that are more convolute and more relevant." ${ }^{11}$ Ingmar Bergman, author of the citation, was among

\footnotetext{
${ }^{1}$ Citation by Ingmar Bergman is also used by Július Pašteka. Refer to PAŠTEKA, Július. Estetické paralely umenia. Bratislava : VEDA, p. 341.
} 
the directors who in their professional careers captured both the theatrical and film space. In the early 1950s, when Bergman made the above statement, there was an intense debate going on about the relationship between theatrical and film languages. The relationship between theatre and film was, for obvious reasons, in the centre of attention not only in the early days of filmmaking. Let us bring to mind the wellknown attempts from the early $20^{\text {th }}$ century, when a kind of hybrid was devised, the "cinema sketch", i.e. the staging of a theatre performance, when a part of it was live stage performance and the other part was film projection, with the same storyline smoothly moving from stage to screen and vice versa.

In the early stages of filmmaking the "help out" of theatre professionals - authors and actors - was natural and even desirable. On the other hand, the transition of theatre into film created antagonistic relationships between theatre and film right from the very beginning of new art. With respect to perception, the booming film art, as opposed to theatre, ushered in an almost perfect illusion of reality: in contrast to theatrical mimesis, it offered a new, up until then, unequalled perception experience. The above Bergman's statement may be contested: even though, at first glance, theatre and film arts seem to be closely related (especially when it comes to the form of reality performance), a closer analysis of the ways in which the two art forms imitate reality shows that by their divergence features, film and theatre tend to be much more apart.

In what, then, does divergence between theatre and film lie? The difference ought to be sought in ontology, in the principle of the coding of actual reality by using film or theatrical language. In the perception of a syncretic work that connects the elements of both the art forms, the viewer a priori perceives theatrical mimesis (and also the execution of theatrical mise-en-scène) as an "alien" element used by the film "language" of a concrete cinematographic work. An alien element is understood as a spill over of certain segments of theatrical language into film language. This is not to imply that available devices are not adequately employed, we only wish to point out that the perception of such a work assumes the viewer's readiness and willingness to accept a hybrid work, which inevitably calls for a different manner of decoding the narrative presented. If we are to summarise the hitherto knowledge which elucidates the relationship between theatre and film (in the manner in which actual reality is imitated and in the subsequent execution of theatrical and film mise-en-scène) it may be concluded that, as opposed to film, theatre enjoys a unique opportunity to imitate actual reality by performing which takes place in real time and in direct interaction between the actor and the viewer. The film conveys this using filmmaking devices. In fact, the reality performed in theatre (mimicking), employs the principle of substitution (oftentimes using pars pro toto). The principle is clearly put to use in the setting up of the mise-en-scène (of the stage) in Lars von Trier's film Dogville (2003), where it is the stage (i.e. the performing space in which actors perform an action) which prevents film methods to be put to use. As regards a specific interaction between film and theatrical languages with respect to the stage component and, unlike Dogville, to the acting component, such antitheatricality of film is also apparent in Anna Karenina (2013), film by Joe Wright. The phenomenon of genre that affects the completed form and the nature of the synthesis of theatrical and film methods is also seen in Moulin Rouge (2001), musical by Baz Luhrmann.

Lars von Trier in Dogville and Joe Wright in Anna Karenina, by declaring the use of theatrical elements, create an allusion of theatre, by which they hint at the antitheatri- 
cality of film. The playwright Karel Čapek writes the following: "The antitheatricality of film is to be seen in the breaking of the closed nature of the so-called dramatic unities of space, time and action." He continues: "What makes film novel, inventive and effective is that despite these properties, it has the capacity to represent and reveal reality more deeply, more fully, and more intensively than any other art." ${ }^{2}$ Mind you, in Čapek's statement the impact, emotional effect upon the recipient and the manner of decoding a work of art by the recipient is interchanged with the manner and form of the imitation of actual reality across different forms of art. Although film is presumably the most syncretic of all arts and it can, in a comprehensive manner and in concurrence at several levels (audio, visual, and textual), convey mediated reality to the viewer, so can any sovereign form of art communicate the information to the recipient by employing specific means and ways peculiar to the art in question. From an ontological point of view the proposition of Július Pašteka, published in Estetické paralely umenia [Aesthetic Parallel of the Arts] appears to be particularly intriguing. Pašteka, by making reference to the Soviet film director Vsevolod Pudovkin, presents the distinction between film and theatre as a difference between types of art: on the one hand, there is film, which conveys reality indirectly, on the other hand, there is theatre which conveys reality directly. According to Pašteka, the film "does not work with real people, real objects, real events in real space and in real time, but rather with the shots of reality, with their 'film images'. Hence, the material basis of a film is not actual reality in its real form but rather in its photographic form, in thousands of still images recorded visually, and ever since the start of the sound era, also acoustically, on a film strip. These images are brought to life using projection, manifesting all the features of real movement, real space, and real time." 3

In the first line of thinking, when formal realisation, stage execution and especially direct contact and interaction between the auditorium and the stage are looked at, it may be stated that theatre is a form of art that conveys actual reality directly, whereas film is a type of art that conveys actual reality indirectly, by employing filmmaking devices. However, when contemplating the essence of the nature and the ontology of these forms of art, their manner of interpretation or perception of a theatrical or cinematographic work, we realise that their imitation of actual reality and the manner of passing over the information code is exactly opposite, that is, cinematic arts, in its essence, conveys reality directly, whereas theatre conveys it indirectly. Theatre space, though presented by real actors, real costumes, stage, props, conveys actual reality indirectly in the vast majority of elements employed by theatre: in actor's interpretation, figuration and stylisation, in the scene setting almost invariably by visual symbolic representation, oftentimes by pars pro toto substitution. In film space, a very good example would be Lars von Trier's Dogville. An unprepared viewer may feel to be cheated on by such direction method. In front of camera reality is conveyed to the viewer in a "standard" two-dimensional space. Although it is only a sign representing actual reality, the viewer will decode the sign in the first line of thinking directly, oftentimes in a semantically unmarked way. The recipient is not frequently confronted with a code he/she is expected to decode: a house on a film screen is a house, a sail is a sail. However, the house in

\footnotetext{
${ }^{2}$ Ibid., p. 320

${ }^{3}$ Ibid., p. 288.
} 
Dogville is realised using theatrical devices, by lines drawn on the stage, to delineate a notional space, the "sign" of the house.

Dogville is a story of Grace (Nicole Kidman), who runs away from city and family evil (a group of gangsters) to hide in Dogville, a tiny village in the midst of mountains. It is a psychological probe into human manipulative conduct. Some critics referred to Trier's Dogville as theatre made into a film. When reflecting upon the film, the viewer, on the basis of his/her experience with the perception of dramatic and film structures, may approach Dogville as a dramatic form. The important fact is the presence of the camera and the manner in which the executed mise-en-scène is recorded. The nature of camera work is suggestive of documentary narrative, it is in constant motion, whereby it does not shun close-ups of especially actors' actions, facial expressions and gestures, as if interfering with the narrative of individual protagonists, to capture critical emotions that gain control over the actors and that are vital for the portrayal of the characters' psychology. This impact upon the recipient may only be achieved by employing cinematic devices. However, this is not doable in theatre, save for some exceptions (chamber theatre, experimental studios, performances in a non-theatre space, where the boundary between the stage and the auditorium is effaced). The producer of a theatre play also has an option to employ experimental form and to use filmmaking equipment to record an actor's action which would be presented to the viewer on a two-dimensional film screen alongside the direct stage action. The difference between a film in which theatrical methods are employed and a "film" which is a recording of theatrical action and, in a broader sense, a recording of a theatre performance, lies in the use of camera, notably, in the capturing of in front of camera reality. In an adapted theatre performance, the author's intervention into the original work is kept at minimum, although by the composition of film cuts, for instance, by use of close-ups, he aims at enriching the original dramatic work. The camera replaces the viewer's eye, it is a transposition of a theatre performance using filmmaking devices onto television screen (film screen). In film production, camera is a standalone semantic unit. The author creates transcription of the original dramatic work (or of a concrete theatre performance) onto television screen (film screen). While in an adapted performance the author aligns the filmmaking gear with the mise-en-scène, in film (or in the adaptation of a dramatic work) the author builds the mise-en-scène and the filmmaking equipment becomes one of the film language layers.

Another sign of theatricality in film structure is "pulling down" the backdrop. Theatre space in which the mise-en-scène is being realised, oscillates between associative and cognitive perceptions of actual reality. The non-existence of the backdrop alludes to the non-existence of a location (a similar solution is also found in television production genre). There is no scenery in Dogville, von Trier removes walls, doors, and windows, which changes the perception of the cinematographic work and alludes to experiments with the realisation of theatre on film. At the same time, at the psychological level, moral attack becomes more powerful. It is as if the director pulled down the walls of the stage house along with prejudice and moral conventions, only to portray a human being as manipulator, soaked through by the egotistic machinery of Dogville inhabitants. The aerial view of the studio from above directly opposes conventional filmmaking. It shows a plan view that defines the stage in the meaning of a theatre stage area, without wings, with just street names marked on the 
plan view. The stage contains minimalistic props and it employs the sound which, with but small exceptions, is not diegetic (opening and closing the doors is audible, although no doors exist, the same applies to the dog barking, etc.).

Among the basic characteristics of the film is the presence of the narrator, by which von Trier alludes to the principles of epic theatre. The storyteller is the basic unit of construction of literary, epic and film work. In Dogville, aside from the primary narrator (we refer to a principle when the narrator is a character in the story, or a classical epic narrator in the third person ${ }^{4}$ ), there is a kind of a secondary narrator, which is the eye of the camera in the film structure. Narration in Dogville is common epic theatre convention, and the film also employs narration with a distancing or 'alienation" effect. This principle is incorporated in theatre and film space from literature, particularly from epic literature. In the materialisation of actual reality and its subsequent segmentation on screen using film montage cinematic art manifests the nature of performance.

Dramatic arts perform actual reality, literature describes it, and film, similarly to theatre, has the nature of performing: "In film, we see and hear everything directly, just like in the real world: the visual is conveyed through visual information, the acoustic via acoustic information. Film enables direct sensual perception of reality, it does not introduce a medium between the viewer and the work, for instance, a mediating language system as a literary work." ${ }^{5}$ As for storyline, cinematic art is similar to literature in that it describes actual reality. That also explains why film is generally understood as an epic and dramatic work. In this context the opinion of the Germanist literary scholar Käte Hamburger is interesting, as she divides literary forms in just two categories, i.e. in "fictional" or "mimetic" form, where she includes epic, drama and film fiction, and "existential" form where she includes the lyric form. ${ }^{6}$ A cinematographic work employs the elements of all the literary forms, not just epic dramatic elements. This was also pinpointed by Emil Staiger in his Poetics - he claims that the elements of all three literary forms (counter to the classicist concept of the purity of forms and genres) take part in the realisation of the work of art, therefore, one cannot refer to a pure form of the lyric, the epic and the drama but rather to a certain degree of the lyric, the epic and the drama present in a concrete work. In a similar spirit, Ernst Cassirer contemplates the ternary nature of the lyric, the epic and the drama which stems in a three-dimensional state. According to him, the past as a remembrance belongs to the lyric, the presence belongs to the epic, and the future to the drama. However, a more accurate time delineation of the individual literary forms is that given by Roman Jakobson. He, by proving mutual agreement between the language grammatical structure and literary forms, claims that the present belongs to the lyric which is formed by the first person, and the past belongs to the epic which is shaped by the third person.

\footnotetext{
${ }^{4}$ In the event the character assumes the role of the narrator (in recent years, the principle has been used rather frequently in cinematic practice), one can speak of the use of the word at the expense of the actor's action and of film montage. It is a kind of 'non-film' element incorporated into cinematic art from literature, or an element of literariness in cinematographic work.

${ }^{5}$ Ibid., p. 303.

${ }^{6}$ Cit. according to KRAUSOVÁ, Nora. Epika a román. Bratislava : Slovenský spisovatel', 1964, p. 51.
} 
Unlike Dogville, which is an original work, in Anna Karenina the adaptation of the originally literary text takes place. The transformation of an epic work into a film takes place at different semiotic levels. It is typical for both the literary (especially prose, in this case, novel) and film works to have identical ontology basis, which is their epic nature, as mentioned above. The existence of their epic nature brings the two structures closer together: an interfering relationship is established between the two by the transcendence of prose (epic) methods into a cinematographic work (let us bring to mind the building of parallel storylines: Anna Karenina - Vronsky, Levin - Kitty and the disruption of the unity of time). The distinction between an epic structure of a novel and its translation into a cinematographic work is that the sign structure of a literary source text is based on a more abstract code. By contrast, the film text is of sensual perception nature, or, of visual and acoustic nature. At the same time, it is created in time and space, at two levels: at the inner text level - let us refer to it as authorial level (kinetic level created by film montage) - and at the outer level, i.e. taking place in concrete time and space of the viewer's perception of a cinematographic work, whereby the viewer is affected by the cinematographic devices that transmit the work onto the film screen (or television screen). If the viewer is familiar with the source text to be adapted, the perception of a cinematographic work will be affected by the extent to which the viewer has identified himself/herself with such an adaptation. The Polish film scholar Alicja Helman writes the following: "The recipient recognises that a film based on a novel is likely to contain numerous modifications and digressions from the original, however, the remembrance of the original will continue to act as a frame of reference. And, with respect to the frame, another important mechanism is triggered, which is rarely activated when watching a film based on an original script (for instance, in remake), and that is the mechanism of comparison between the book and the film."7

As stated above, an interesting example of the interference between theatrical and film methods, using the literary prototext which constitutes the basis of film adaptation, is Anna Karenina. Tolstoy's novel has had several television and film adaptations. Apparently, this must have been the reason why director Joe Wright opted for an approach to the literary source which made his film utterly different from other film adaptations. He ventured to devise a novel form of the adaptation of a classical theme by connecting theatrical and film elements, which was a method tested out in experimental film workshops. The Russian theatre tradition offered film-makers the possibility to employ theatricality in film form, especially modernism in Russian drama. An allusion to Russian modernism in the film is, for instance, the scene of a horse race, which takes place on stage. By erecting a house ${ }^{8}$ on the stage, the director stylises the story in collective scenes (dance, work in the factory), whereby he employs the elements of a musical or dance theatre. The form is markedly syncretic, and the elements of theatrical and film methods overlap at several layers of the work structure. It is this specific form used in Wright's adaptation that prompts the question, much more imperatively than in Dogville, whether this is not theatre shot on camera. The effect of theatricality is reached in Anna Karenina in

${ }^{7}$ HELMANOVÁ, Alicja. Tvořivá zrada. Filmové adaptace literárních děl. In Tvořivé zrady. Současné polské myšlení o filmu a audiovizuální kultuře. Praha : Národní filmový archiv, 2005, p. 141. ISBN 80-7004-119-6.

${ }^{8}$ A house on the stage in the meaning of the construction of scenery. 
several areas, most profoundly in the building of mise-en-scènes, in the use of the performing area and in the stylisation of actors' actions which at times are closer to stage acting than to film acting. Anna Karenina in Joe Wright's interpretation is a specific film adaptation of a generally known theme, completely different from all previous adaptations. One may refer to a fantasy portrayal of a timeless story. The used theatrical elements serve as a metaphor which enables Wright to comment on the main themes in Anna Karenina and, above all, they help build a contrast. The film is innovative, resourceful in execution, and it even creates antagonistic lines (city - countryside, immoral - moral, theatre - film, epic time - dramatic time). ${ }^{9}$ The film captivates the viewer by its technical virtuosity, narrative convolutedness, theatrical mise-en-scène in film form and in the context with the film mise-en-scène, it creates a compact whole. One might argue that Anna Karenina lapses into aesthetic mannerism, that the form supersedes the content or emotional narrative. We are convinced, though, it is an original construct, or, rather "deconstruct" of an original work and its translation into a film form.

Alicja Helman points at the basic categorisation of the forms of an adaptation of a literary work, making reference to a classical categorisation of Geoffrey Wagner, Michael Klein and Gillian Parker who base themselves on a three-tier model of film adaptation with respect to the original literary prototext:

a) fidelity to a source text,

b) preservation of the basic construction of a literary source in its film adaptation,

c) loose adaptation of the basic motives of a source text in cinematographic work. ${ }^{10}$

Wright's Anna Karenina is an example of the vast diversity of forms and of the capturing of the literary source in a film adaptation. Each time, authorial personalities of the creative team will step into the building of a completed work who transform the literary source in ever-new combinations of several semantic layers. Thus, a specific film form is created which, sometimes more and sometimes less, alludes to its source material. When making the novel adaptation, Joe Wright eliminated excessive epic and static description and he put emphasis on the alternation of several formal elements. This helped him achieve different variations of the source text and by interconnecting film and theatrical elements, he moved from linear construction to its segmentation. Wright's film adaptation is the best proof that the adaptation of a literary prototext is a fairly complex process and each time, it entails a unique way

\footnotetext{
${ }^{9}$ An interesting opinion on capturing and defining dramatic time is offered by theatre scholar Jan Vedral: "A non-theatrology summary of a theatrology research is a conclusion that in drama, "time behaves as if it were alive". Time is a composition ingredient that gives drama, as an image of human conduct, its inner life." Refer to VEDRAL, Jan. Horizont události (Dramaturgie řádu, postdramaturgie chaosu). Bratislava : Ústav divadelnej a filmovej vedy SAV, 2015, p. 142. ISBN 978-80-86102-95-5.

${ }^{10}$ Three groups, forms of relationship between a cinematographic work and its literary source, which are close to the classical categorisation in the text, are laid down by Ivan Stadtrucker, who works with the concepts of transcription, analogy, improvisation. Refer to STADTRUCKER, Ivan. Dramaturgia hraného filmu. Bratislava : Tatra, 1990, pp. 79 - 80. ISBN 80-222-0172-3. An interesting classification is offered by Brian McFarlan, who defines only two methods of film adaptation, i.e. transfer and adaptation per se. Alicja Helman comments on the model as follows: "That which belongs to the narrative, that which is not connected with a single semiological system and can be directly transposed into film is subject to transfer. By contrast, that which belongs to enunciation, that which is connected with a single semiologic system requires adaptation. In other words, its object is an expression inventory thanks to which the narrated story can be related." Refer to HELMANOVÁ, Alicja. Tvořivá zrada. Filmové adaptace literárních děl. In Tvořivá zrada. Současné polské myšlení o filmu a audiovizuální kultuře, p. 135.
} 
of the transcription of one "medium" code to another. By way of conclusion it can be said that there are as many modes and models of adaptations as there are adaptations of literary source texts.

Translated by Mária Švecová

\author{
Ján Sabol \\ Filozofická fakulta Univerzity Pavla Jozefa Šafárika \\ Šrobárova 2 \\ 04059 Košice \\ Slovakia \\ e-mail: jansabol@pobox.sk
}

